Article

\title{
Evaluation of a Low-Cost Ceramic Filter for Sustainable Reuse of Urban Stormwater in Arid Environments
}

\author{
Md. Shafiquzzaman ${ }^{1, *(\mathbb{D}}$, Husnain Haider ${ }^{1}{ }^{(}$, Yousry Mahmoud Ghazaw ${ }^{1,2}{ }^{1}$ Fawaz Alharbi ${ }^{1}$, \\ Saleem S. AlSaleem ${ }^{1}$ (D) and Meshal Almoshaogeh ${ }^{1}$ (D) \\ 1 Department of Civil Engineering, College of Engineering, Qassim University, Buraydah 51452, Saudi Arabia; \\ husnain@qec.edu.sa (H.H.); ghazaw@qec.edu.sa (Y.M.G.); f.a@qec.edu.sa (F.A.); \\ alsaleem@qec.edu.sa (S.S.A.); m.moshaogeh@qec.edu.sa (M.A.) \\ 2 Department of Irrigation and Hydraulics, College of Engineering, Alexandria University, \\ Alexandria 21544, Egypt \\ * Correspondence: shafiq@qec.edu.sa; Tel.: +966-580-811-458
}

Received: 27 December 2019; Accepted: 7 February 2020; Published: 9 February 2020

check for updates

\begin{abstract}
Sustainable reuse of urban stormwater is inevitable in the fight against water crises in arid regions. This research aimed to evaluate the effectiveness of a low-cost ceramic filtration process for reuse applications of urban stormwater. Stormwater was collected from a storage pond located in Buraydah (Qassim, Saudi Arabia) for laboratory experiments. The filtration tests were performed in a continuous mode with constant pressure using a low-cost ceramic filter made of clay soil and rice bran. The removal rates of the contaminants (heavy metals) as well as the turbidity, suspended solids, and nutrients of the stormwater were assessed. High removal efficiencies for turbidity (97.4\%), suspended solids $(97.0 \%), \mathrm{BOD}_{5}(78.4 \%)$, and COD $(76.1 \%)$ were achieved while low removals were achieved for the nutrients: $19.7 \%$ for total nitrogen, $25.3 \%$ for nitrate, and $8.6 \%$ for phosphate. Removal efficiencies ranged between $36.2 \%$ and $99.9 \%$ for the heavy metals, i.e., iron, manganese, lead, zinc, nickel, copper, cadmium, selenium, and barium. Contaminant removal rates observed for the ceramic filter were also compared with the alum coagulation process operated in a continuous mode at an optimum alum dose of $50 \mathrm{mg} / \mathrm{L}$. Similar removal behaviors for removal of turbidity, suspended solids, organics, nutrients, and heavy metals suggested that both ceramic filtration and alum coagulation can be effectively used for stormwater treatment. Effluent qualities of both the ceramic filter and alum coagulation met the standards, for recycling/reuse of wastewater, set by the Kingdom of Saudi Arabia and World Health Organization for unrestricted irrigation and toilet flushing. The study results revealed that ceramic filtration is a low-cost, energy efficient, and easy to maintain technology which can be complimentary to best management practices for stormwater.
\end{abstract}

Keywords: stormwater management; ceramic filter; alum coagulation; low-cost treatment; contaminants removal

\section{Introduction}

Most of the urban areas in arid and semi-arid environmental regions are focusing on innovative and sustainable approaches for stormwater management, such as integrated greywater and stormwater reuse for green buildings, groundwater recharge through infiltration ponds, and improved drainage systems with retention storages [1]. Appropriate urban stormwater management can reduce both the hydraulic and pollution loads on drainage system and enrich the groundwater resources [2]. Recycling of stormwater for non-drinking applications or for groundwater recharge needs to be applied for sustainable stormwater management as well as for protection of the environment [3]. 
Urban stormwater runoff transports a wide range of pollutants (generated by anthropogenic and biogenic activities) into the receiving water bodies (i.e., retention ponds and natural drains) that exceed the maximum contamination limits set for recycling as well as groundwater recharge. Stormwater runoff can be polluted by organics, nutrients such as phosphorus and nitrogen, hydrocarbons, oils, and heavy metals originating from fertilizers, automobile emissions, agriculture, soil erosion, yard waste, and detergents [4-6]. Moreover, stormwater can be contaminated by intrusion of emerging pollutants from cross-contamination or overflows of municipal sewers $[7,8]$.

Physical, chemical, and microbiological characteristics of stormwater usually do not comply with the desired water quality standards either for non-potable water applications or artificial groundwater recharge [9-11]. Several low-impact design (LID) technologies including bioswales, constructed wetlands, vegetated filter strips, and media filters have been employed for stormwater management [12-14]. Some of the LID techniques such as bioswales, constructed wetlands, and vegetated filter strips simulate the use of natural systems, which can effectively reduce pollutants from stormwater and subsequently minimize the runoff through infiltration and evapotranspiration [12]. Media filter is a relatively recent LID technique which can filter the runoff collected by the storm drains $[13,15]$. Raingardens and bioswales are effective to remove organic and inorganic contaminants $[4,15,16]$. The performance of conventional sand filters was reported as poor to moderate for the removal of particulate organics, nutrients, and heavy metals ( $\mathrm{Cd}, \mathrm{Cu}, \mathrm{Pb}, \mathrm{Ni}, \mathrm{Cr}$, and $\mathrm{Zn})$ [17]. Vegetated bioretention systems have shown higher performance for removal of organic constituents and metals from stormwater $[4,6,18]$. Although the above-mentioned LID techniques are technically sound, the application of these technologies may not be feasible in arid and semi-arid regions with a low amount of annual precipitation [19]. Other approaches such as low-cost filtration would be more feasible in these regions.

Chemical treatment such coagulation/flocculation is a well-established process used for water and wastewater treatment. Alum and ferric based coagulants were found to be highly effective to destabilize and remove the colloidal fraction through flocculation and sedimentation [20]. Effectiveness of these processes has rarely been evaluated for the treatment of stormwater. In a few studies, the coagulation and flocculation processes were applied either individually or in conjunction with filtration [21-25]. Although these studies show promising results, the processes may have some operational and economical drawbacks, primarily associated with the use of chemicals. Also, the treatment plant operators constantly need to monitor the coagulant dose to ensure smooth running of the system.

Membrane filtration techniques such as microfiltration (MF) and ultrafiltration (UF) have been widely recognized for water and wastewater treatment for the past several years. Microfiltration and Ultrafiltration are typically applied for drinking water and municipal sewage treatment [26,27]. Recently, both MF and UF membrane processes were effectively applied to treat harvested rainwater [28-31]. High cost and frequent fouling of membrane are likely to be the key drawbacks in applying commercial MF or UF for stormwater treatment in developing countries. Hence, there is a dire need to develop low-energy and cost-effective stormwater treatment technologies in arid and semi-arid regions that can reduce the variety of contaminants from stormwater.

Recently, a low-cost ceramic micro filter, made of clay soil and rice bran, was developed and tested for the treatment of arsenic contaminated groundwater, domestic wastewater, domestic greywater, and sand filter backwash water [32-35]. Study conducted by Hassan et al. [32] showed that a micro-porous ceramic filter together with a zero valent iron netting was highly effective for removal of arsenic and iron from the groundwater and could be a cost-effective treatment technology for arsenic contaminated regions. In other studies, this ceramic filter removed more than $90 \%$ organics from domestic wastewater and greywater $[32,34]$. The same filter, combined with the coagulation and flocculation processes, was tested for treating sand filter backwash water and produced high-quality recyclable water [35].

The suitability of this filter for stormwater treatment has not been evaluated so far, which was the primary motivation for this research. The characteristics of stormwater significantly differ from both 
wastewater and greywater due to the presence of various heavy metals [36]. Therefore, evaluating the extent of heavy metal removal from stormwater using the developed ceramic filter is a novel contribution of the present research which has not been investigated in past studies.

The aim of this study is to apply a low-cost ceramic micro-filter for stormwater treatment. The specific objectives are to: (i) perform characterization of stormwater, (ii) investigate the efficiency of the ceramic filter for the removal of various contaminants from stormwater through filtration experiments, (iii) compare the contaminant removal performance of the ceramic filer with the alum coagulation process, and (iv) evaluate the prospects of recycling and groundwater recharge of the treated stormwater.

\section{Materials and Methods}

\subsection{Stormwater Sampling}

Stormwater was collected from the stormwater storage pond located at $26.3489^{\circ} \mathrm{N}$ and $43.7668^{\circ}$ E in Qassim University (QU) Campus, Buraydah (Qassim, Saudi Arabia). The pond with an area of $2500 \mathrm{~m}^{2}$ receives stormwater from the catchment area of approximately $1.4 \mathrm{~km}^{2}$. The catchment area (i.e., QU Campus) mainly consists of academic and administration buildings, a hospital, parking areas, staff residence buildings, and landscape plantation. Since 2016, various construction activities have also been carried out in this catchment for new academic buildings, a gymnasium, and plantation in the parking zones. The pond fills with stormwater during the rainy season from December to April and becomes dry through infiltration and evaporation by mid-summer, i.e., June and July. To obtain fresh stormwater for analysis, samplings were conducted immediately after the storm event (with $24.2 \mathrm{~mm}$ rainfall) on 16 February, 2019. As the climate of the study area is characterized as arid and the rainy season comes in winter, the possibility of biological activity is negligible. Triplicate samples were collected from three different locations in pre-washed high- density polyethylene (HDPE) bottles and transported to the laboratory for succeeding analysis. All the samples were stored in refrigerator at $4{ }^{\circ} \mathrm{C}$ without any treatment and analyzed for $\mathrm{pH}$, dissolve oxygen (DO), biochemical oxygen demand $\left(\mathrm{BOD}_{5}\right)$, and chemical oxygen demand (COD) within $48 \mathrm{~h}$ of sampling. For other water quality tests, the samples were preserved in acid washed glass bottles and sent to the General Directorate of Water in Qassim Region, Saudi Arabia. Sufficient volume of stormwater was collected to conduct filtration and coagulation tests within $48 \mathrm{~h}$ of sample collection.

\subsection{Physico-Chemical Analysis}

Physico-chemical analyses were performed according to the methods defined by the American Public Health Association [37]. Electrical conductivity (EC), pH, and DO were measured using the Hach (HACH, Loveland, CO, USA) portable $\mathrm{pH}, \mathrm{EC}$, and DO meter. Turbidity was measured with the help of a Hach 2100Q turbidity meter (2100Q, HACH, Loveland, CO, USA). Total dissolve solids (TDS) were measured using Hach HQ411d TDS meter (HACH, Loveland, CO, US). Alkalinity was measured by titration with sulfuric acid. BOD was measured following the standard procedure of the 5-day BOD test (5210: 2000). Total organic carbon (TOC) was determined by a TOC analyzer (Shimadzu, Japan). A Hach-DR5000 UV-Vis spectrophotometer was used to measure COD (Closed Reflux, Colorimetric Method 5220 D: 2000), and $\mathrm{PO}_{4}-\mathrm{P}$ (4500-P E. ascorbic acid method). Total nitrogen (TN) was measured by the Kjeldahl method (4500- $\mathrm{N}_{\text {org }}$ B: 2000). $\mathrm{NO}_{3}-\mathrm{N}, \mathrm{NO}_{2}-\mathrm{N}$ and $\mathrm{NH}_{3}-\mathrm{N}_{\text {were measured, }}$ respectively by the nitrate electrode method (4500- $\left.\mathrm{NO}_{3} \mathrm{D}: 2000\right)$, colorimetric method (4500- $\mathrm{NO}_{2} \mathrm{~B}$ : 2000), and titrimetric method (4500- $\left.\mathrm{NH}_{3} \mathrm{C}: 2000\right)$. Metals of toxicological concern including $\mathrm{Fe}, \mathrm{Mn}, \mathrm{Pb}$, $\mathrm{Zn}, \mathrm{Ni}, \mathrm{Cu}, \mathrm{Cd}$, Se, Ba, and $\mathrm{Cr}$ were measured using an Inductive coupled Plasma Mass Spectrometer (PerkinElmer, NexIONTM 300 ICP-MS) [38]. The Limit of quantification (LOQ ) for different metals for ICP-MS in $\mu \mathrm{g} / \mathrm{L}$ were: Fe 0,7, Mn 0.7, Zn 1.0, Pb 0.4, Ni 0.6, Cu 0.6,Cd 0.7, Cr 0,8, Ba 0.5, and Se 0.8. 


\subsection{Ceramic Filter}

The low-cost micropores ceramic filter used in this study was manufactured using locally available clay soil and rice bran. Details manufacturing process of the filter is described in the authors' previous study [39]. The final filter was cylindrical in shape (see Table 1 and Figure 1a), having pore size of $1-5 \mu \mathrm{m}$ and the manufacturing cost was 0.2-0.3 US\$/filter [39].

Table 1. Characteristics of ceramic filter and operating conditions of the filtration process.

\begin{tabular}{cc}
\hline \multicolumn{1}{c}{ Characteristics of Filter } \\
Material & Clay \\
Pore size $(\mu \mathrm{m})$ & $1-5$ \\
Shape & Cylindrical \\
Height $(\mathrm{mm})$ & 100 \\
Module external diameter $(\mathrm{mm})$ & 100 \\
Module internal diameter $(\mathrm{mm})$ & 60 \\
Filtration area $\left(\mathrm{cm}^{2}\right)$ & 390 \\
\hline Operating Conditions of Filtration Process & \\
\hline Configuration & Fully submerged \\
Pressure (Kpa) & 3.2 \\
Aeration rate & Not controlled \\
Filtration time $(\mathrm{h})$ & 72 \\
Feed volume $(\mathrm{L})$ & 300 \\
\hline
\end{tabular}

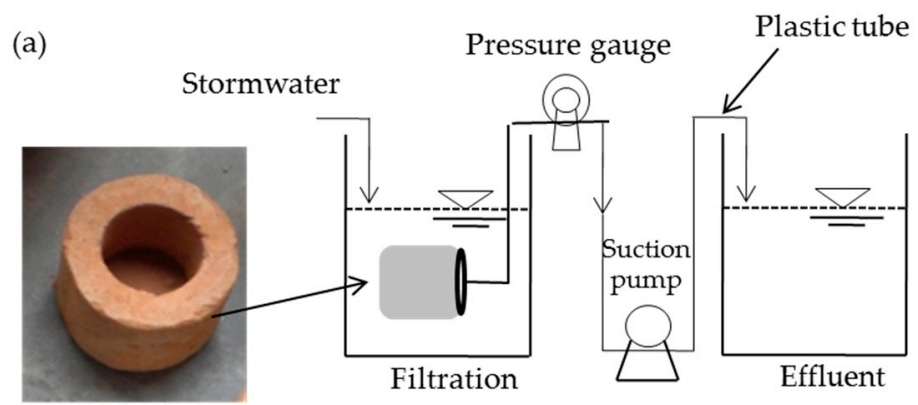

Ceramic filter

(b)

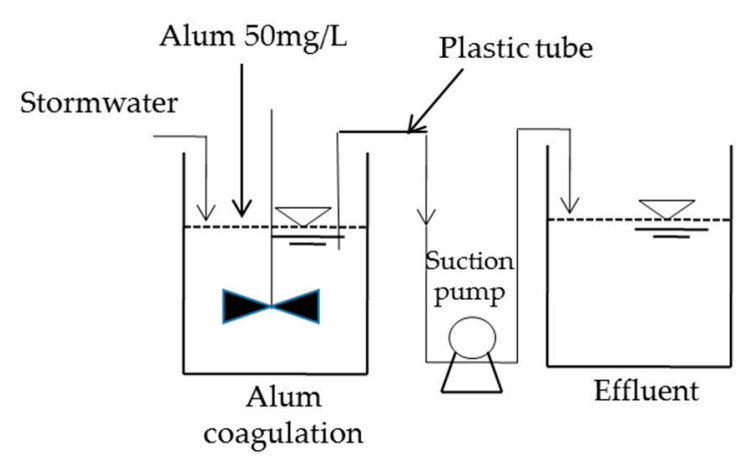

Figure 1. Schematic diagram of continuous (a) Stand-alone ceramic filtration test and (b) alum coagulation test.

\subsection{Alum as Coagulant}

Powdered aluminum sulfate hydrate $\left(\mathrm{Al}_{2}\left(\mathrm{SO}_{4}\right)_{3} \cdot 12 \mathrm{H} 2 \mathrm{O}\right)$ was used as the coagulant (WETICO-Water and Environment Technologies Co., Ltd., Kingdom of Saudi Arabia (KSA)). Alum solution was prepared by mixing of alum powder with distilled water and used for coagulation experiments. 


\subsection{Stormwater Treatment Experiments}

Two laboratory scale stormwater treatment processes were tested, including ceramic filtration and alum coagulation (see Figure 1a,b). The ceramic filtration unit consisted of a filtration tank and an effluent tank. In the filtration experiments, raw stormwater was manually fed to the filtration tank where the ceramic filter was submerged horizontally on a plastic board to ensure an effective use of the entire surface of the filter (Figure 1a). The open side of the filter was sealed by a rubber cap with a small opening for the effluent tube. A vacuum pump was used to filter the water by suction. The effluent tube made of plastic and $6 \mathrm{~mm}$ in diameter was used to connect the filter, through the vacuum pump to the effluent tank. Filtration was conducted at a constant pressure of $3.2 \mathrm{KPa}$. During the filtration period, the permeate flux and pressure were monitored on an hourly basis to investigate the possible fouling of the filter. In order to prevent the fouling materials accumulated on the filter, air was provided by a diffusor without controlling the aeration rate. The permeate (final water) was directed through the effluent tube to the effluent tank. Filter permeate was collected on a daily basis and analyzed for water quality. The operating conditions of the ceramic filtration test are shown in Table 1.

Continuous alum coagulation experiments were performed in a coagulation tank at $50 \mathrm{mg} / \mathrm{L}$ of optimum alum dose (see Figure 1b). A two minute rapid mixing (at $100 \mathrm{rpm}$ ) was followed by slow mixing (at $40 \mathrm{rpm}$ ) for $20 \mathrm{~min}$ and final settling for $30 \mathrm{~min}$ [40]. Subsequently, the suspension was transferred to the final effluent tank for water quality analysis. The experiments were performed on three consecutive days to ensure reproducibility. In order to determine the optimum alum dose for the continuous alum coagulation experiment, a standard jar test was carried at room temperature $\left(25^{\circ} \mathrm{C}\right)$ and $\mathrm{pH}$ varied between 7.81 and 8.19 . For the jar tests, $0,15,30,50,100,150$, and $200 \mathrm{mg} / \mathrm{L}$ of alum were separately added to 7 glass beakers containing $1000 \mathrm{~mL}$ stormwater. The beakers were then placed under the jar tester (JM4, Nvatech International). The suspensions of each glass beaker were carefully obtained and analyzed for residual concentrations of contaminants in order to determine the optimal dose of alum.

\subsection{Statistical Analysis}

Microsoft Excel software was used to perform the independent t-test to establish the significance of removal performances between ceramic filtration and alum coagulation treatment processes. The removal difference is considered to be statistically significant for $p$-value $<0.05$.

\section{Results and Discussion}

\subsection{Storm Water Quality}

Table 2 shows the characteristics of storm water collected from the surface storage pond constructed within Qassim University (QU) campus. It can be seen in the table that $\mathrm{pH}$ values are in the desirable range for any reuse purpose. Turbidity $(32.7 \pm 2.7 \mathrm{NTU})$ and total suspended solids (TSS) (721 $\pm 49 \mathrm{mg} / \mathrm{L})$ concentrations were high and exceeded the standard limit for drinking water and reuse application set by both KSA and World Health Organization (WHO) [41-44]. Total dissolved solids (TDS) and electrical conductivity (EC) were lower than the standard limit for reuse application set by Saudi Arabia (MWE) and the World Health Organization (WHO) [41,42].

It can be seen in Table 2 that turbidity, total suspended solids (TSS), $\mathrm{BOD}_{5}$, and COD were found to be higher than both the reuse and drinking water standard set by KSA as well as the WHO [41-44]. As autumn was the prior season of the sampling period, such values of $\mathrm{BOD}_{5}$ can be attributed to the fallen leaves from trees which possibly became a part of surface runoff and ultimately reached the pond. Moreover, the pond may have decomposed plants that may mix during sampling and may increase the organics that would not typically be found in stormwater. Low concentrations of $\mathrm{N}$ and $\mathrm{P}$ were found in stormwater which can possibly be associated with the limited use of fertilizers for 
plantation in the catchment. Previous study reported higher N and P concentrations in stormwater due to extensive use of fertilizers [45].

Table 2. Physico-chemical quality of stormwater collected from QU campus pond and typical values of stormwater.

\begin{tabular}{|c|c|c|c|c|}
\hline \multirow{2}{*}{ Parameter } & \multirow{2}{*}{ Unit } & \multicolumn{2}{|c|}{ Storm Water Quality of This Study } & \multirow{2}{*}{$\begin{array}{c}\begin{array}{c}\text { Typical Values of } \\
\text { Stormwater }\end{array} \\
\text { Arithmetic Mean }\end{array}$} \\
\hline & & Mean * & Stdev & \\
\hline $\mathrm{pH}$ & - & 8.32 & 0.05 & 6.9 \\
\hline $\mathrm{DO}$ & $\mathrm{mg} / \mathrm{L}$ & 7.53 & 0.42 & \\
\hline Turbidity & NTU & 32.67 & 2.70 & 172 \\
\hline TSS & $\mathrm{mg} / \mathrm{L}$ & 721.00 & 49.12 & 294 \\
\hline TDS & $\mathrm{mg} / \mathrm{L}$ & 344.33 & 60.35 & - \\
\hline EC & $\mathrm{us} / \mathrm{cm}$ & 457.33 & 36.12 & - \\
\hline Alkalinity $\left(\mathrm{CaCO}_{3}\right)$ & $\mathrm{mg} / \mathrm{L}$ & 88.33 & 5.69 & - \\
\hline $\mathrm{BOD}_{5}$ & $\mathrm{mg} / \mathrm{L}$ & 60.67 & 3.51 & 18 \\
\hline COD & $\mathrm{mg} / \mathrm{L}$ & 94.47 & 7.31 & 108 \\
\hline TOC & $\mathrm{mg} / \mathrm{L}$ & 11.69 & 1.49 & 33 \\
\hline $\mathrm{TN}$ & $\mathrm{mg} / \mathrm{L}$ & 1.82 & 0.08 & 3.4 \\
\hline $\mathrm{NH}_{3}-\mathrm{N}$ & $\mathrm{mg} / \mathrm{L}$ & 0.60 & 0.04 & - \\
\hline $\mathrm{NO}_{2}-\mathrm{N}$ & $\mathrm{mg} / \mathrm{L}$ & 0.20 & 0.04 & - \\
\hline $\mathrm{NO}_{3}-\mathrm{N}$ & $\mathrm{mg} / \mathrm{L}$ & 1.62 & 0.10 & - \\
\hline $\mathrm{PO}_{4}-\mathrm{P}$ & $\mathrm{mg} / \mathrm{L}$ & 0.18 & 0.04 & 0.46 \\
\hline $\mathrm{Fe}$ & $\mathrm{mg} / \mathrm{L}$ & 0.29 & 0.05 & 6.8 \\
\hline $\mathrm{Mn}$ & $\mathrm{mg} / \mathrm{L}$ & 0.06 & 0.02 & 0.37 \\
\hline $\mathrm{Cu}$ & $\mu \mathrm{g} / \mathrm{L}$ & 108.69 & 12.63 & 130 \\
\hline $\mathrm{Zn}$ & $\mu \mathrm{g} / \mathrm{L}$ & 333.63 & 30.06 & 500 \\
\hline $\mathrm{Ba}$ & $\mu \mathrm{g} / \mathrm{L}$ & 41.30 & 3.68 & - \\
\hline $\mathrm{Cr}$ & $\mu \mathrm{g} / \mathrm{L}$ & 13.89 & 1.41 & 77 \\
\hline $\mathrm{Pb}$ & $\mu \mathrm{g} / \mathrm{L}$ & 25.98 & 3.80 & 270 \\
\hline Se & $\mu \mathrm{g} / \mathrm{L}$ & 31.31 & 7.68 & - \\
\hline $\mathrm{Cd}$ & $\mu \mathrm{g} / \mathrm{L}$ & - & - & 11 \\
\hline $\mathrm{Ni}$ & $\mu \mathrm{g} / \mathrm{L}$ & - & - & 40 \\
\hline
\end{tabular}

$\mathrm{ND}=$ Not detected,$*$ The average of triplicate samples.

Several species of metals including, $\mathrm{Fe}, \mathrm{Mn}, \mathrm{Cu}, \mathrm{Zn}, \mathrm{Ba}, \mathrm{Cr}, \mathrm{Pb}$, and Se were found in the stormwater which might have originated from the pavement erosion, leakage of oils from vehicles in parking areas and roads, vehicular emissions, abrasion of tires and brakes, and soil erosion [46,47]. Among the heavy metals, selenium Se concentration $(31.31 \pm 7.8 \mu \mathrm{g} / \mathrm{L})$ exceeded the reuse and drinking water standard limits established by both the KSA and WHO. Cadmium (Cd) and Ni were not detected in the studied stormwater. Many of the pollutants listed in this study would have broken down (such as N) or be removed (such as heavy metals) as the stormwater infiltrated through the soil [48]. Conversely, many were added due to their natural occurrence in the soil.

Table 2 shows a comparison between the studied stormwater qualities with typical stormwater data found in the literature [49]. Turbidity, $\mathrm{TN}$ and $\mathrm{PO}_{4}-\mathrm{P}$ concentrations in studied stormwater were lower than the typical mean value of stormwater reported by Duncan [49]. TSS, BOD5, and COD were found to be higher than the typical mean value [49]. Concentrations of heavy metals were also lower than the typical stormwater values [49]. Analysis of the stormwater in the present study revealed that the stormwater needs to be treated for recharging or recycling in order to prevent the pollution of both the soil and groundwater. 


\subsection{Ceramic Filtration Experiments}

\subsubsection{Permeate Flux and Pressure Data}

The pressure and permeate flux variations during $72 \mathrm{~h}$ continuous filtration of stormwater are presented in Figure 2. The permeate flux was within the range of 103 to $109 \mathrm{~L} / \mathrm{m}^{2} / \mathrm{h}$ and did not change significantly during $72 \mathrm{~h}$ of continuous filtration. The pressure was maintained between $3.19 \mathrm{KPa}$ and 3.26 KPa. At this range of pressure, filtration was completed without backwashing as the flux did not decline during the operation.

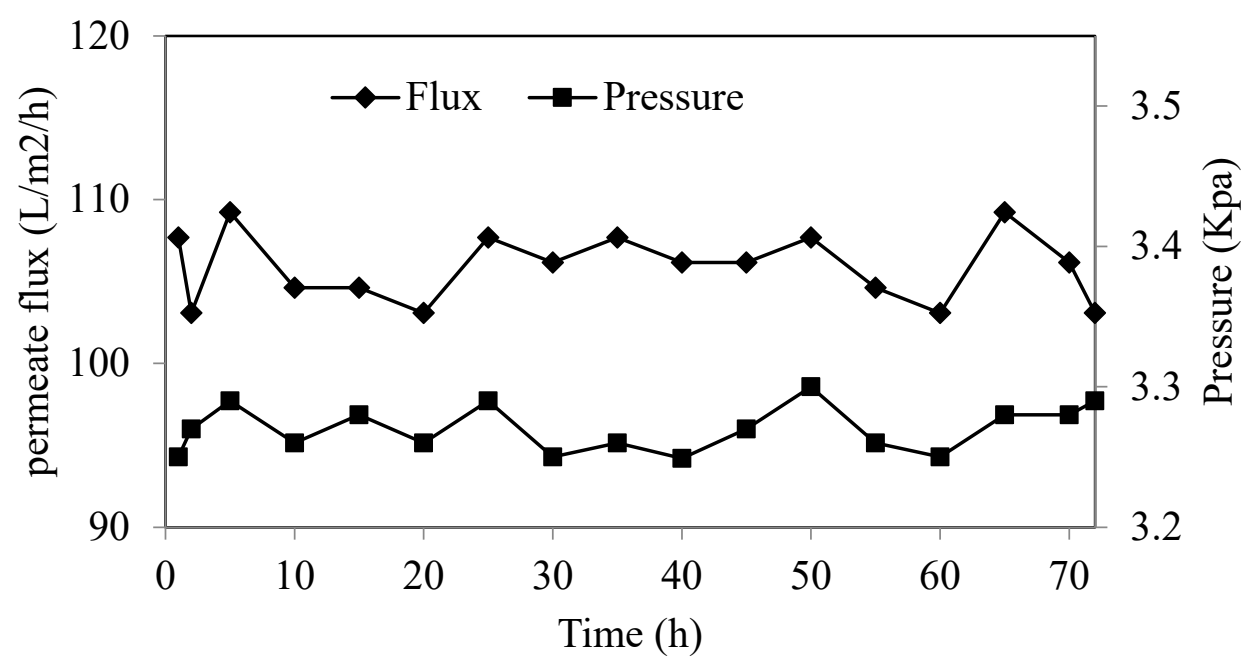

Figure 2. Permeate flux and pressure data during ceramic filtration experiments.

Although long-term clogging behavior was not investigated, it can be assumed that this ceramic filtration can continuously operate for longer durations without being clogged [35]. A continuous aeration was performed in the filtration tank to prevent the irreversible fouling of the filter which further improved the antifouling ability of the filter. Nevertheless, it is recommended to clean the filter on a regular basis using a soft brush, instead of a conventional backwash process to avoid clogging [35]. The ceramic filter had a comparative flux with respect to recently studied UF and MF filtration techniques achieving 60-265 L/h-m ${ }^{2}$ for MF and 80-220 L/h-m² for UF [46]. However, the operating conditions and effluent quality criteria depend on the reuse application of the treated stormwater.

\subsubsection{Physico-Chemical Water Quality of Filter Effluents}

Table 3 shows $\mathrm{pH}$ and DO values before and after filtration operation. The value of $\mathrm{pH}$ was 8.37 before the filtration unit. After filtration, $\mathrm{pH}$ was not significantly changed and remained within the range of 8.29 and 8.45 in the effluent. These findings suggested no need for $\mathrm{pH}$ adjustment during the filtration operation. A slight decrease of DO was observed during filtration from $8.0 \mathrm{mg} / \mathrm{L}$ to an average of 7.65 in the effluent. Average values of alkalinity and EC remained almost unchanged with $93 \mathrm{mg} / \mathrm{L}$ and $429 \mu \mathrm{s} / \mathrm{cm}$ in the influent and $91.3 \mathrm{mg} / \mathrm{L}$ and $456 \mu \mathrm{s} / \mathrm{cm}$ in the effluent.

\subsubsection{Removal of Turbidity, TSS and TDS}

Removal of turbidity, TSS, and TDS from stormwater is presented in Table 3. It can be seen that the ceramic filter achieved $97.4 \%$ of turbidity removal with an average effluent value of 0.7 NTU. Moe than $97 \%$ removal of TSS was also achieved with the average TSS value of $7.76 \mathrm{mg} / \mathrm{L}$ in the effluent indicating that the ceramic filter is highly efficient in removing both the colloidal and suspended particles from the stormwater. TDS concentrations did not change and remained the same in both the influent and effluent. Nevertheless, the TDS of none of the stormwater samples exceeded the standard limit. The removal performances of turbidity, TSS and TDS observed in this study are comparable with 
the findings of previous studies that MF membranes are highly effective for removing turbidity and TSS from greywater but ineffective for removal of TDS [50,51].

\subsubsection{Removal of Organic and Nutrients}

Table 3 presents the removal performances of BOD5, COD, and TOC by the studied ceramic filter. The average BOD5 removal efficiency was achieved $78.4 \%$. The effluent of the filter produced an average $13.8 \pm 1.4 \mathrm{mg} / \mathrm{L}$ of BOD with no observations higher than $15 \mathrm{mg} / \mathrm{L}$. COD removal was achieved as $76.1 \%$. The effluent of the filter contained an average COD value of $24.0 \pm 6.1 \mathrm{mg} / \mathrm{L}$; while all the samples were found with COD values less than $30 \mathrm{mg} / \mathrm{L}$. These results indicate that the particulate portion of organics was removed by the physical straining of the micro-porous ceramic filter surface. Furthermore, higher organics (more than 75\% of both BOD and COD) removals suggest that some portion of dissolved organics was also removed through adsorption on to the natural clay based ceramic filter used in this study. A previous study by Ogunmodede et al. [52] also reported that natural clay has some sorption capabilities for organics from wastewater. The percentage removals for turbidity, TSS, and TDS presented in Table 3 are comparable with the other LID technologies [53,54].

Concentrations of $\mathrm{TN}, \mathrm{NO}_{3}-\mathrm{N}$, and $\mathrm{PO}_{4}-\mathrm{P}$ in the filtrate are shown in Table 3. Analysis of three samples collected during the filtration showed that the concentration of $\mathrm{TN}$ was reduced from $1.84 \mathrm{mg} / \mathrm{L}$ to an average of $1.48 \pm 0.07 \mathrm{mg} / \mathrm{L}$, nitrate dropped from 1.52 to $1.14 \pm 0.36 \mathrm{mg} / \mathrm{L}$, and $\mathrm{PO}_{4}-\mathrm{P}$ dropped from $0.15 \mathrm{mg} / \mathrm{L}$ to $0.14 \pm 0.04 \mathrm{mg} / \mathrm{L}$. Slight increase of phosphate in run $1(0.18 \mathrm{mg} / \mathrm{L})$ and nitrate in run $2(1.56 \mathrm{mg} / \mathrm{L})$ in the effluent indicated possible release of these ions at the beginning from the clay based ceramic filter. Interestingly, the release did not persist for long as the other two samples showed lower concentrations of $\mathrm{PO}_{4}-\mathrm{P}$ and $\mathrm{NO}_{3}-\mathrm{N}$ in the effluent. The percentage removals for $\mathrm{TN}$ and $\mathrm{NO}_{3}-\mathrm{N}$ and $\mathrm{PO}_{4}-\mathrm{P}$ were found to be $19.7 \%, 25.3 \%$, and $8.6 \%$, respectively. As per these findings, the efficiency of the ceramic filter is relatively low in terms of nutrient removal from stormwater. The slight removal of nutrients by the ceramic filters can be attributed to possible adsorption of nitrate and phosphate anions onto the clay-based filter [55].

\subsubsection{Removal of Heavy Metals}

The performance of ceramic filter in terms of heavy metal removal is presented in Table 3. Results in the table show that the effectiveness of the filter is moderate to high for removing heavy metals from stormwater excluding $\mathrm{Cr}$. The following percentage removals were achieved: $84.7 \%$ for $\mathrm{Fe}, 62.8 \%$ for $\mathrm{Mn}, 56.7 \%$ for $\mathrm{Cu}, 36.2 \%$ for $\mathrm{Zn}, 42.2 \%$ for $\mathrm{Ba}$, and more than $99 \%$ for $\mathrm{Pb}$ and Se. The effect of $\mathrm{pH}$ is the most critical parameter for oxidation and formation of metal precipitation during the filtration process. In this study, filtration experiments were conducted at $\mathrm{pH} 8.37$ with a slight change, between 8.29 and 8.45 in the effluent (Table 3). At this range of $\mathrm{pH}$, most of the metals can be precipitated [56] and removed by the micro-porous ceramic filter. Nonspecific electrostatic adsorption of cationic metals on the clay-based filter might be another mechanism to remove heavy metals in this study [57]. Due to the reversed mechanism of $\mathrm{Cr}$ mobility [58,59], a different trend was shown and $\mathrm{Cr}$ was not removed though filtration (see Table 3). Heavy metal removal by ceramic filtration comparable with other LID technologies (Table 3) indicates the suitability of our filter in arid and semi-arid regions where conventional LID technologies are not feasible. 
Table 3. Effluent water quality of ceramic filtration of this study and others LID technologies.

\begin{tabular}{|c|c|c|c|c|c|c|c|c|}
\hline \multirow{2}{*}{ Parameters } & \multicolumn{4}{|c|}{ Contaminant Removal by Ceramic Filtration (This Study) } & \multicolumn{4}{|c|}{ Contaminant Removal \% by Other LID Technologies } \\
\hline & Influent & Effluent * & Stdev & Removal (\%) * & $\begin{array}{c}\text { Bio-Retention } \\
\text { Systems [53] }\end{array}$ & $\begin{array}{c}\text { Permeable } \\
\text { Pavements [53] }\end{array}$ & $\begin{array}{c}\text { Grass } \\
\text { Swales [53] }\end{array}$ & Sand Filter $[54]$ \\
\hline $\mathrm{pH}$ & 8.37 & 8.38 & 0.08 & - & - & - & - & - \\
\hline $\mathrm{DO}(\mathrm{mg} / \mathrm{L})$ & 8.00 & 7.65 & 0.14 & - & - & - & - & - \\
\hline $\begin{array}{l}\text { Alkalinity }(\mathrm{mg} / \mathrm{L} \\
\left.\text { as } \mathrm{CaCO}_{3}\right)\end{array}$ & 93.0 & 91.3 & 4.1 & 6.5 & - & - & - & - \\
\hline EC (us/cm) & 429.0 & 456.3 & 41.1 & -8.9 & - & - & - & -0.92 \\
\hline Turbidity (NTU) & 30.3 & 0.7 & 0.2 & 97.4 & & & & \\
\hline TSS (mg/L) & 774.0 & 7.7 & 1.12 & 97.0 & 47-99 & $58-94$ & $46-97$ & $32-93.5$ \\
\hline $\mathrm{TDS}(\mathrm{mg} / \mathrm{L})$ & 279.0 & 292.0 & 25.6 & -3.6 & - & - & - & - \\
\hline $\mathrm{BOD}_{5}(\mathrm{mg} / \mathrm{L})$ & 64.0 & 13.8 & 1.4 & 78.4 & - & - & - & - \\
\hline $\mathrm{COD}(\mathrm{mg} / \mathrm{L})$ & 102.4 & 24.5 & 6.1 & 76.1 & - & - & - & - \\
\hline $\mathrm{TOC}(\mathrm{mg} / \mathrm{L})$ & 10.1 & 9.8 & 1.2 & 2.9 & - & - & $23-64$ & - \\
\hline $\mathrm{TN}(\mathrm{mg} / \mathrm{L})$ & 1.84 & 1.48 & 0.07 & 19.7 & $32-99$ & $>75$ & $14-61$ & $-33.8-73.8$ \\
\hline $\mathrm{NO}_{3}-\mathrm{N}(\mathrm{mg} / \mathrm{L})$ & 1.52 & 1.14 & 0.36 & 25.3 & $1-83$ & & $-143-45$ & $-104.3-70$ \\
\hline $\mathrm{PO}_{4}-\mathrm{P}(\mathrm{mg} / \mathrm{L})$ & 0.15 & 0.14 & 0.04 & 8.6 & - & - & - & $-600-66$ \\
\hline $\mathrm{Fe}(\mathrm{mg} / \mathrm{L})$ & 0.23 & 0.0 & 0.0 & 84.7 & - & - & - & - \\
\hline $\operatorname{Mn}(\mathrm{mg} / \mathrm{L})$ & 0.06 & 0.0 & 0.0 & 62.8 & - & - & - & - \\
\hline $\mathrm{Cu}(\mathrm{ug} / \mathrm{L})$ & 95.06 & 41.2 & 11.9 & 56.7 & $43-97$ & $20-99$ & $14-67$ & $-15-68$ \\
\hline $\mathrm{Zn}(\mathrm{ug} / \mathrm{L})$ & 301 & 192 & 49.5 & 36.2 & $62-97$ & $73-99$ & $47-81$ & $0-93$ \\
\hline $\mathrm{Ba}(\mathrm{ug} / \mathrm{L})$ & 37.19 & 21.5 & 6.1 & 42.2 & - & - & - & - \\
\hline $\mathrm{Cr}(\mathrm{ug} / \mathrm{L})$ & 13.66 & 18.2 & 7.0 & -32.9 & - & - & - & - \\
\hline $\mathrm{Pb}(\mathrm{ug} / \mathrm{L})$ & 22.63 & - & - & $>99 \%$ & $31-98$ & 75-99 & 18-94 & $-24-98$ \\
\hline Se (ug/L) & 22.63 & - & - & $>99 \%$ & - & - & - & - \\
\hline $\mathrm{Cd}(\mathrm{ug} / \mathrm{L})$ & ND & - & - & - & - & - & $12-98$ & - \\
\hline $\mathrm{Ni}(\mathrm{ug} / \mathrm{L})$ & ND & - & - & - & - & - & - & - \\
\hline
\end{tabular}




\subsection{Stormwater Treatment by Alum Coagulation and Comparison with Ceramic Filtration}

\subsubsection{Determining the Optimum Alum Dose}

Heavy metal removals at different alum dosing (jar test) are presented in Figure 3. pH values corresponding to the alum doses shown in Figure 3 describe the $\mathrm{pH}$ increase from 7.2 to 8.2 with the increase of alum dose from $0 \mathrm{mg} / \mathrm{L}$ to $200 \mathrm{mg} / \mathrm{L}$. Based on the residual concentrations of different metals, it can be clearly observed in Figure 3 that the maximum removal for most of the metals was achieved at $15-50 \mathrm{mg} / \mathrm{L}$ of alum dose. However, $50 \mathrm{mg} / \mathrm{L}$ of alum dose provided the best removal (except $\mathrm{Mn}$ ) as shown in Figure 3. Residual metal concentrations increased at alum doses higher than $50 \mathrm{mg} / \mathrm{L}$. Hence the optimal dose of alum was selected as $50 \mathrm{mg} / \mathrm{L}$ to carry out the stormwater treatment by alum coagulation. At $50 \mathrm{mg} / \mathrm{L}$ alum dose, the $\mathrm{pH}$ of the solution was more than 8.03 (Figure 3) and most of the alum precipitated as alum hydroxide. Consequently, most of the cationic metals were absorbed and precipitated with the hydroxide flocs.

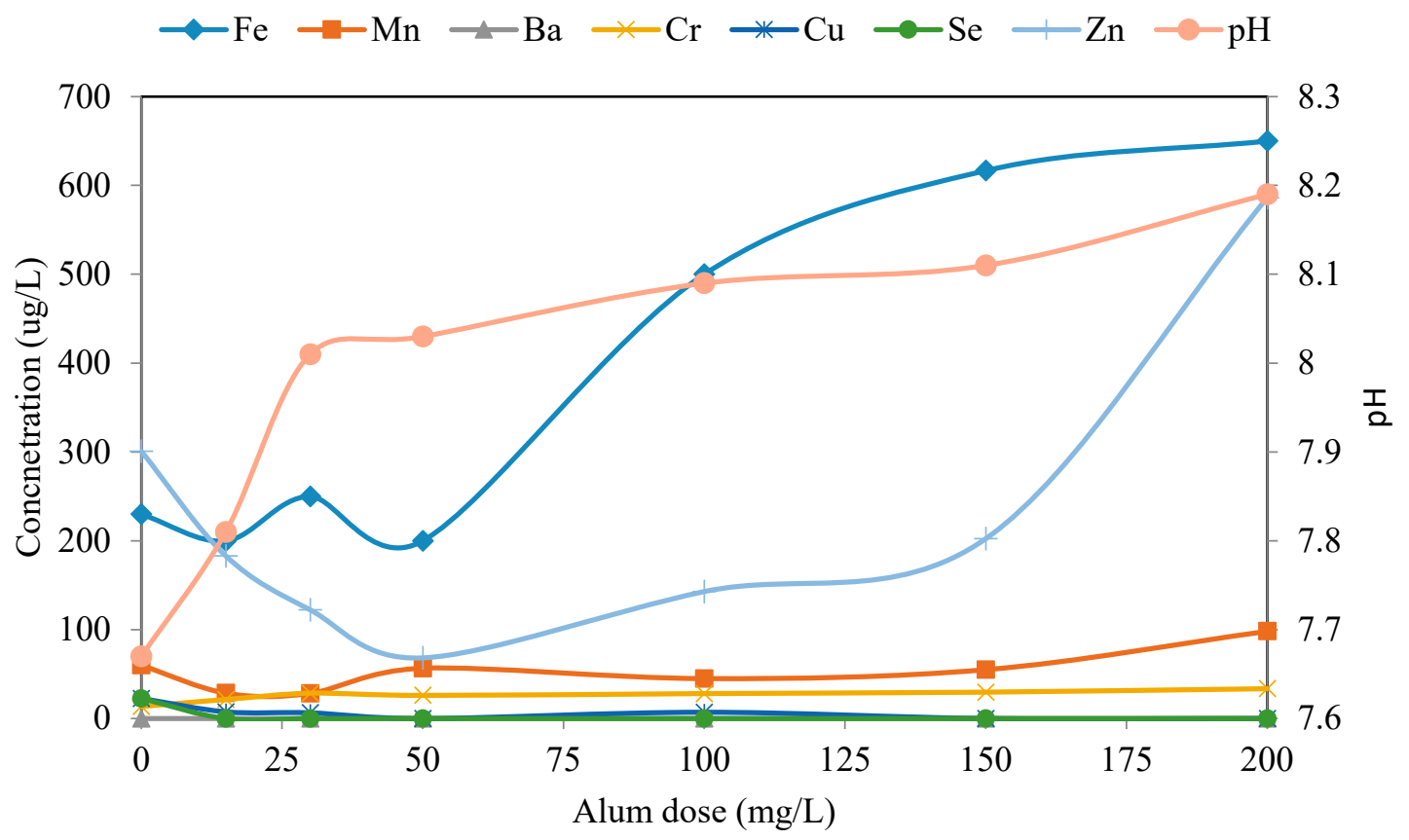

Figure 3. Residual concentrations of heavy metals at different alum doses (Jar test). $\mathrm{pH}=7.7-8.2$; temperature $=250{ }^{\circ} \mathrm{C}$.

\subsubsection{Contaminants Removal by Alum Coagulation and Comparison with Ceramic Filtration}

Performances of the alum coagulation and ceramic filter were compared in terms of contaminant removals to identify the more efficient option for stormwater treatment. Figure 4 presents the comparison of turbidity, organics, and nutrient removal between ceramic filtration and alum coagulation. Removal performances of the two treatment processes were compared through a t-test. Both treatment processes achieved more than $95 \%$ turbidity removal and showed no significant difference between the two processes (i.e., $p=0.08$ ). $\mathrm{BOD}_{5}$ and COD removals were more than $60 \%$ for both the processes and showed no significant difference $(p=0.2)$.

Both the processes showed almost similar performance in terms of nutrient removals. The difference was found statistically insignificant for $\mathrm{TN}, \mathrm{NO}_{3}-\mathrm{N}$, and $\mathrm{PO}_{4}-\mathrm{P}(p>0.05)$. Nitrate removal through coagulation and flocculation can be attributed to sweep precipitation and adsorption on to the aluminum hydroxide flocs that were formed at $\mathrm{pH}$ above 8 in the solution [60]. The removal of $\mathrm{PO}_{4}-\mathrm{P}$ can be explained by the possible complex reaction and precipitation mechanism. Phosphorus was possibly removed by the formation of insoluble $\mathrm{AlPO}_{4}$ which is adsorbed on to the floc and then precipitated [61]. 
Performance of ceramic filter and alum coagulation in terms of heavy metal removal is presented in Figure 5. T-test results showed that except Fe $(p<0.05)$, no significant difference was observed for heavy metal removal by both the processes $(p>0.05)$. More than $50 \%$ average percentage of heavy metal removal was achieved for all the metals except, $\mathrm{Zn}, \mathrm{Ba}$, and $\mathrm{Cr}$. Chromium was not removed in either of the processes (data not shown in Figure 4). For $\mathrm{Pb}$ and $\mathrm{Se}, 99 \%$ removal was achieved by both the processes. In the alum coagulation process, individual metal precipitation and adsorption of metal ions onto the flocculated aluminum hydroxide can be considered as the key removal mechanism in the present study [62].

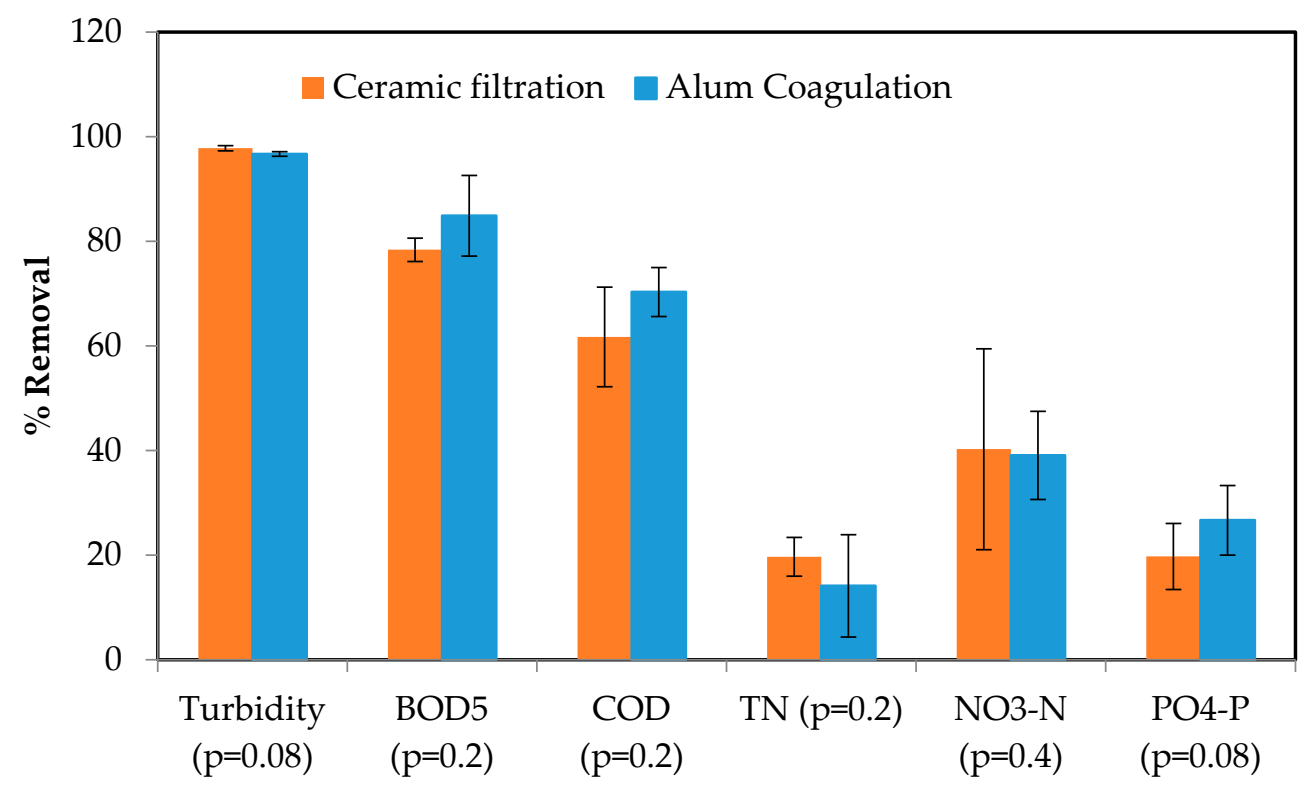

Figure 4. Removal \% of turbidity, organics and nutrients by ceramic filtration and alum coagulation. Error bars show the standard deviation of triplicate samples. P values show the statistical significance of the two processes derived from a paired t-test.

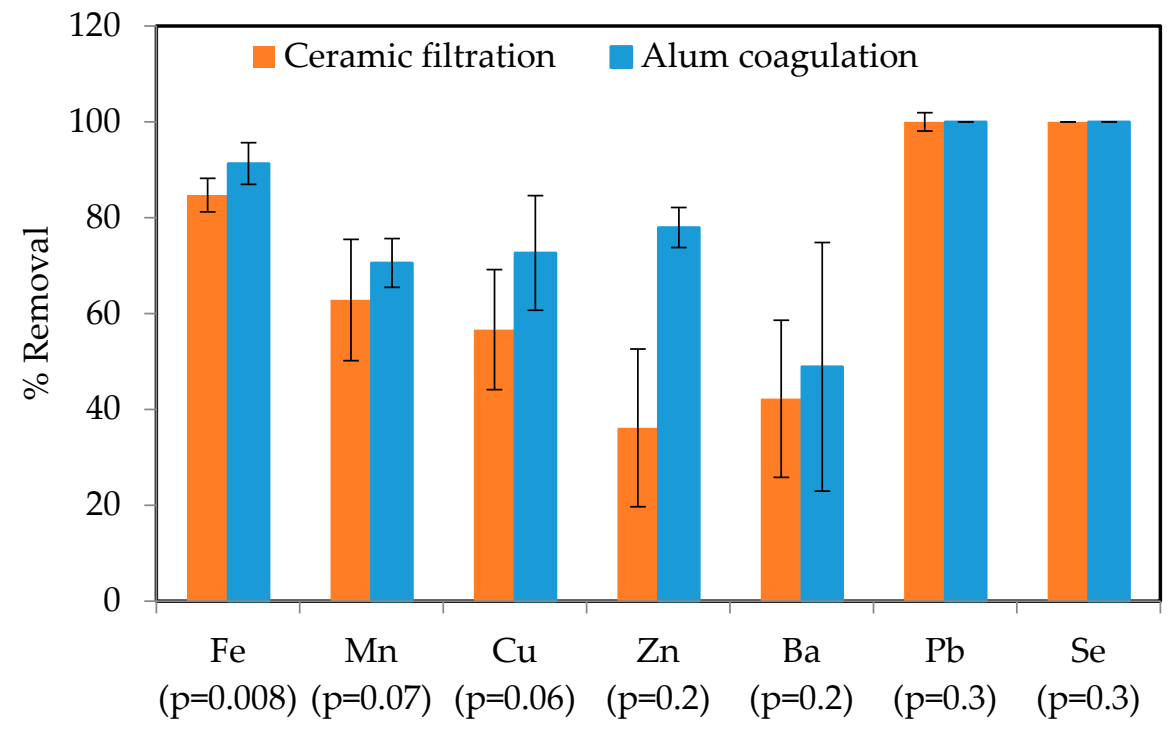

Figure 5. Removal \% of heavy metals by ceramic filtration and alum coagulation. Error bars show the standard deviation of triplicate samples. P values show the statistical significance of the two processes derived from a paired t-test. 


\subsection{Prospects and Application of Ceramic Filter for Stormwater Management and Reuse}

The effluent qualities of the ceramic filter and alum coagulation were assessed using both the wastewater reuse guidelines and safe drinking water quality standards issued by the Ministry of Water and Electricity, Kingdom of Saudi Arabia (MWE) [41], Saudi Arabia Standard Organization (SAO) [44] and World Health Organization (WHO) [42,43]. Drinking water quality standards set by both the organizations (SAO and WHO) are used herein as the guideline values for direct recharge of groundwater as the recharge should neither degrade the groundwater quality nor impose any additional treatment after pumping. The reuse application-guides by both the MWE and WHO are applicable for unrestricted irrigation, fire protection, and toilet flushing. The range of water quality concentrations of the effluents of ceramic filter and alum coagulation with the standard limits are presented in Table 4. Both ceramic filter and alum coagulation showed good water quality for these reuse applications. However, the presence of organics ( $\mathrm{BOD}_{5}$ and $\mathrm{COD}$ ) in stormwater requires an advanced treatment such as reverse osmosis ( $\mathrm{RO}$ ) to meet the water quality standards for applications such as potable use or recharging groundwater.

$\mathrm{pH}$, Turbidity, and TDS in the effluents of both treatment processes were found under the prescribed limits for reuse applications. BOD $_{5}$ and COD were also below the standard limit for both the processes as shown in Table 4. Nutrients $\left(\mathrm{TN}, \mathrm{NO}_{3}-\mathrm{N}\right.$, and $\mathrm{PO}_{4}-\mathrm{P}$ ) concentrations in the raw stormwater were found to be lower than the standard limit for both the drinking water and reuse application which were further reduced in the effluents of both the treatment processes. Among the heavy metals, Se concentrations $(0.023 \mathrm{mg} / \mathrm{L})$ in raw stormwater exceeded the standard limit of $0.02 \mathrm{mg} / \mathrm{L}$ set by both the organizations for reuse applications while the concentrations were reduced below the detection limits in both the effluents and met the desired standards. Although, Cr was increased to reach concentrations slightly higher than the respective raw stormwater concentrations, the level was always found to be lower in the effluents of both the processes (Table 4). Although, the efficiency of the treatment processes in terms of microbiological water quality was not investigated in this study, a simple disinfection process is recommended for reusing or groundwater recharging application of treated stormwater.

Both the treatment processes exhibited almost similar behaviors for removal of organics, nutrients, and heavy metals and were found to be effective methods for stormwater treatment. It is important to mention that in a previous research by the authors, the cost of a ceramic filter $\left(0.53 \$ / \mathrm{m}^{3}\right)$ was found to be significantly lower than the cost of alum coagulation $\left(0.67 \$ / \mathrm{m}^{3}\right)$ for ablution greywater treatment [63]. Study results suggest that the use of a low-cost ceramic filter would be more economically and environmentally sustainable than the use of alum coagulation for the treatment of stormwater. Moreover, a ceramic filter is easy to maintain with prolonged operations without being clogged and has low sludge production due to chemical-free operations. The ceramic filtration system consumes low energy due to the requirements of low pressure (3.2 $\mathrm{KPa})$, eventually giving low operating cost. The ceramic filter also does not require highly skilled operators as a very simple and effective cleaning procedure using a soft brush is recommended instead of a conventional backwash process [32,34,35]. Although other LID technologies require low maintenance and operating costs, a ceramic filter would be more feasible for arid and semi-arid regions with low amount of annual precipitation as the filtration system can be operated intermittently based on the availability of the rainwater. Nevertheless, the raw stormwater in the present study was less polluted by heavy metals. Therefore, further studies are suggested to assess the effectiveness of a ceramic filter for treating more polluted stormwater. 
Table 4. Stormwater quality of two processes and standard limits for recycling and drinking water.

\begin{tabular}{|c|c|c|c|c|c|c|c|}
\hline Parameter & RAW & $\begin{array}{l}\text { Ceramic Filter } \\
\text { Effluent }\end{array}$ & $\begin{array}{c}\text { Alum Coagulation } \\
\text { Effluent }\end{array}$ & $\begin{array}{l}\text { KSA Reuse } \\
\text { Standard }\end{array}$ & $\begin{array}{l}\text { WHO Reuse } \\
\text { Standard }\end{array}$ & $\begin{array}{l}\text { KSA Drinking } \\
\text { Water Standard }\end{array}$ & $\begin{array}{l}\text { WHO Drinking } \\
\text { Water Standard }\end{array}$ \\
\hline $\mathrm{pH}$ & 8.37 & & & $6-8.4$ & $6.0-9.0$ & $6.5-8.5$ & $6.5-8$ \\
\hline Turbidity (NTU) & 30.3 & $0.5-0.8$ & $0.89-1.15$ & 5 & - & $<5$ & - \\
\hline TSS (mg/L) & 774 & $<5$ & $<5$ & 10 & - & & - \\
\hline TDS (mg/L) & 279 & $298-302$ & $399-400$ & 2500 & - & 700 & - \\
\hline $\mathrm{BOD}_{5}(\mathrm{mg} / \mathrm{L})$ & 64 & $12-15$ & $4-13$ & 10 & 10 & & - \\
\hline $\mathrm{COD}(\mathrm{mg} / \mathrm{L})$ & 102.4 & $18.3-30.5$ & $19.0-22.2$ & 50 & - & - & - \\
\hline $\mathrm{NH}_{3}-\mathrm{N}(\mathrm{mg} / \mathrm{L})$ & 1.52 & $0.17-0.21$ & $0.10-0.12$ & 5 & - & - & - \\
\hline $\mathrm{NO}_{3}-\mathrm{N}(\mathrm{mg} / \mathrm{L})$ & 1.9 & $0.95-1.5$ & $1.02-1.33$ & 10 & - & - & - \\
\hline $\mathrm{Fe}(\mathrm{mg} / \mathrm{L})$ & 0.23 & $0.03-0.044$ & $0.15-0.2$ & 5 & 5 & 0.3 & 0.3 \\
\hline $\mathrm{Mn}(\mathrm{mg} / \mathrm{L})$ & 0.06 & $0.014-0.028$ & $0.024-0.042$ & 0.2 & 0.2 & 0.1 & 0.1 \\
\hline $\mathrm{Cu}(\mathrm{mg} / \mathrm{L})$ & 0.095 & $28.0-51.2$ & $54.3-65.9$ & 0.3 & 0.2 & 1 & 2 \\
\hline $\mathrm{Zn}(\mathrm{mg} / \mathrm{L})$ & 0.31 & $139-237$ & $68-231$ & 4 & 2 & 5 & 3 \\
\hline $\mathrm{Cr}(\mathrm{mg} / \mathrm{L})$ & 0.013 & $13.6-26.2$ & $13.2-21$ & 0.1 & 0.1 & 0.05 & 0.05 \\
\hline $\mathrm{Pb}(\mathrm{mg} / \mathrm{L})$ & 0.023 & ND & ND & 0.1 & 5 & 0.05 & 0.01 \\
\hline $\mathrm{Se}(\mathrm{mg} / \mathrm{L})$ & 0.023 & ND & ND & 0.02 & 0.02 & 0.01 & 0.04 \\
\hline $\mathrm{Cd}(\mathrm{mg} / \mathrm{L})$ & ND & ND & ND & 0.01 & 0.1 & 0.005 & 0.003 \\
\hline $\mathrm{Ni}(\mathrm{mg} / \mathrm{L})$ & ND & ND & ND & 0.2 & 0.2 & - & 0.07 \\
\hline
\end{tabular}




\section{Conclusions and Recommendations}

Stormwater treatment by a low-cost ceramic filter offers a sustainable stormwater management system for non-potable reuse applications in arid regions. Ceramic filtration showed an efficient and cost-effective alternative that meets the water quality standards for unrestricted irrigation, toilet flushing, and fire protection set by the KSA and the WHO. Nevertheless, microbial quality must be controlled through disinfection to ensure public health safety. The following percentage removals were achieved after treating the stormwater with a ceramic filter: $95 \%$ for turbidity, $78.4 \%$ for BOD5, and $76.1 \%$ for COD. Performance in terms of nutrient removal was also satisfactory. Ceramic filter exhibited moderate to high removals of heavy metals including iron, manganese, lead, zinc, and selenium. Comparison of the removal performances between the ceramics filter and the alum coagulation manifested almost similar behavior for a range of contaminants. Although, the ceramic filter and alum coagulation can be alternatively used for the treatment of stormwater, ceramic filtration is a more sustainable option with low cost, easy maintenance, flexible and chemical free operations, and low energy consumption. Overall, the ceramic filter has a great potential to replace the filter media of conventional treatment systems for the optimum stormwater management in arid and semi-arid regions. As, the experiments were carried out in this study for short duration, a more detailed feasibility study is recommended to evaluate long-term performance of the filter under varying conditions, such as intensity of precipitation, hydraulic variables, operating conditions, energy consumption, and complementary criteria. As the stormwater investigated in the present research had relatively low heavy metal content, further studies are also recommended to evaluate the effectiveness of the ceramic filter for the treatment of stormwater with higher concentrations of heavy metals.

Author Contributions: M.S. worked on conceptualization, methodology, experimental design data analysis, and preparation of original draft. H.H. reviewed the results and methodology and edited the draft manuscript. Y.M.G. was involved in performing experiments. F.A. was responsible for water quality analysis at the Water Directorate of Buraydah. S.S.A., and M.A. were involved in provision of logistics and project administration. All authors have read and agreed to the published version of the manuscript.

Funding: This research was funded by Deanship of Scientific Research, Qassim University with grant no. 3880-qec-2018-1-14-S.

Acknowledgments: This work was supported by Deanship of Scientific Research at Qassim University with grant no. 3880-qec-2018-1-14-S. Authors highly acknowledge the General Directorate of Water in Qassim Region for supporting in analyzing the water quality in the central laboratory.

Conflicts of Interest: We hereby declare no conflict of interest.

\section{References}

1. Haider, H.; Ghumman, A.R.; Al-Salamah, I.S.; Ghazaw, Y.; Abdel-Maguid, R.H. Sustainability evaluation of rainwater harvesting based flood risk management strategies: A multilevel decision-making framework for arid environments. Arab. J. Sci. Eng. 2019, 10, 8465-8488. [CrossRef]

2. Hering, J.G.; Waite, T.D.; Luthy, R.G.; Drewes, J.E.; Sedlak, D.L. A changing framework for urban water systems. Environ. Sci. Technol. 2013, 47, 10721-10726. [CrossRef]

3. National Academies of Science. Using Graywater and Stormwater to Enhance Local Water Supplies: An Assessment of the Risks, Costs, and Benefit. National Academies of Science, Engineering and Medicine; National Academies Press: Washington, DC, USA, 2016.

4. Davis, A.P.; Shokouhian, M.; Sharma, H.; Minami, C. Water quality improvement through bioretention media: Nitrogen and phosphorus removal. Water. Environ. Res. 2006, 78, 284-293. [CrossRef]

5. Grebel, J.E.; Mohanty, S.K.; Torkelson, A.A.; Boehm, A.B.; Higgins, C.P.; Maxwell, R.M.; Nelson, K.L.; Sedlak, D.L. Engineered infiltration systems for urban stormwater reclamation. Environ. Eng. Sci. 2013, 30, 437-454. [CrossRef]

6. LeFevre, G.H.; Paus, K.H.; Natarajan, P.; Gulliver, J.S.; Novak, P.J.; Hozalski, R.M. Review of dissolved pollutants in urban storm water and their removal and fate in bioretention cells. J. Environ. Eng. 2015, 141, 4014050. [CrossRef] 
7. Emmanouil, C.; Bekyrou, M.; Psomopoulos, C.; Kungolos, A. An Insight into Ingredients of Toxicological Interest in Personal Care Products and A Small-Scale Sampling Survey of the Greek Market: Delineating a Potential Contamination Source for Water Resources. Water 2019, 11, 2501. [CrossRef]

8. Deblonde, T.; Cossu-Leguille, C.; Hartemann, P. Emerging pollutants in wastewater: A review of the literature. Int. J. Hygiene Environ Health 2011, 214, 442-448. [CrossRef]

9. Zhu, K.; Zhang, L.; Hart, W.; Liu, M.; Chen, H. Quality issues in harvested rainwater in arid and semi-arid Loess Plateau of northern China. J. Arid. Environ. 2004, 57, 487-505. [CrossRef]

10. Aryal, R.; Vigneswaran, S.; Kandasamy, J.; Naidu, R. Urban stormwater quality and treatment. Korean J. Chem. Eng. 2010, 27, 1343-1359. [CrossRef]

11. Reddy, K.R.; Xie, T.; Dastgheibi, S. Adsorption of mixtures of nutrients and heavy metals in simulated urban stormwater by different filter materials. J. Environ. Sci. Health A 2014, 49, 524-539. [CrossRef] [PubMed]

12. Yu, J.; Yu, H.; Xu, L. Performance evaluation of various stormwater best management practices. Environ. Sci. Pollut. Res. 2013, 20, 6160-6171. [CrossRef] [PubMed]

13. Reddy, K.R.; Xie, T.; Dastgheibi, S. Mixed-media filter system for removal of multiple contaminants from urban storm water: Large-scale laboratory testing. J. Hazard. Toxic. Radioact. Waste 2014, 18, 1-8. [CrossRef]

14. Anderson, B.S.; Phillips, B.M.; Voorhees, J.P.; Siegler, K.; Tjeerdema, R. Bioswales reduce contaminants associated with toxicity in urban storm water. Environ. Toxicol. Chem. 2016, 35, 3124-3134. [CrossRef]

15. Hatt, B.E.; Fletcher, T.D.; Deletic, A. Hydraulic and pollutant removal performance of stormwater filters under variable wetting and drying regimes. Water Sci. Technol. 2007, 56, 11-19. [CrossRef]

16. LeFevre, G.H.; Hozalski, R.M.; Novak, P.J. The role of biodegradation in limiting the accumulation of petroleum hydrocarbons in raingarden soils. Water Res. 2012, 46, 6753-6762. [CrossRef] [PubMed]

17. Reddy, K.R.; Xie, T.; Dastgheibi, S. Removal of heavy metals from urban stormwater runoff using different filter materials. J. Environ. Chem. Eng. 2014, 2, 282-292. [CrossRef]

18. Zhang, K.; Randelovic, A.; Page, D.; McCarthy, D.T.; Deletic, A. The validation of stormwater biofilters for micropollutant removal using in situ challenge tests. Ecol. Eng. 2014, 67, 1-10. [CrossRef]

19. Gautam, M.R.; Acharya, K.; Stone, M. Best management practices for stormwater management in the desert southwest. J. Contemp. Water Res. Educ. 2010, 146, 39-49. [CrossRef]

20. Bratby, J. Coagulation and Flocculation in Water and Wastewater Treatment, 3rd ed.; IWA Publishing: London, UK, 2016.

21. Heinzmann, B. Coagulation and flocculation of stormwater from a separate sewer system-A new possibility for enhanced treatment. Water Sci. Technol. 1994, 29, 267-278. [CrossRef]

22. Trejo-Gaytan, J.; Bachand, P.; Darby, J. Treatment of urban runoff at Lake Tahoe: Low-intensity chemical dosing. Water Environ. Res. 2006, 78, 2487-2500. [CrossRef]

23. Kang, J.H.; Li, Y.; Lau, S.L.; Kayhanian, M.; Stenstrom, M.K. Particle destabilization in highway runoff to optimize pollutant removal. J. Environ. Eng. 2007, 133, 426-434. [CrossRef]

24. Sansalone, J.J.; Kim, J.Y. Suspended particle destabilization in retained urban stormwater as a function of coagulant dosage and redox conditions. Water Res. 2008, 42, 909-922. [CrossRef]

25. Nyström, F.; Nordqvist, K.; Herrmann, I.; Hedström, A.; Viklander, M. Treatment of road runoff by coagulation/flocculation and sedimentation. Water Sci. Technol. 2019, 79, 518-525. [CrossRef] [PubMed]

26. Scott, K. Introduction to Membrane Separations, Handbook of Industrial Membranes; Elsevier Science: Oxford, UK, 1998.

27. Badrnezhad, R.; Ben, A.H. Ultrafiltration membrane process for produced water treatment: Experimental and modeling. J. Water Reuse Desalination 2013, 3, 249. [CrossRef]

28. Peter-Varbanets, M.; Zurbrügg, C.; Swartz, C.; Pronk, W. Decentralized systems for potable water and the potential of membrane technology. Water Res. 2009, 43, 245-265. [CrossRef]

29. Arnal, J.M.; García-Fayos, B.; Sancho, M.; Verdú, G.; Lora, J. Design and installation of a decentralized drinking water system based on ultrafiltration in Mozambique. Desalination 2010, 250, 613-617. [CrossRef]

30. Dobrowsky, P.H.; Lombard, M.; Cloete, W.J.; Saayman, M.; Cloete, T.E.; Carstens, M.; Khan, S.; Khan, W. Efficiency of microfiltration systems for the removal of bacterial and viral contaminants from surface and rainwater. Water Air Soil Pollut. 2015, 226, 33. [CrossRef]

31. Miorando, T.; Brião, V.B.; Girardelli, L. Ultrafiltration of rainwater to produce drinking water. Environ. Sanit. Eng. 2017, 22, 481-490. 
32. Hasan, M.M.; Shafiquzzaman, M.; Azam, M.S.; Nakajima, J. Application of a simple ceramic filter to membrane bioreactor. Desalination 2011, 276, 272-277. [CrossRef]

33. Hasan, M.M.; Shafiquzzaman, M.; Nakajima, J.; Bari, Q.H. Application of a simple arsenic removal filter in rural area of Bangladesh. IWA Water Sci. Technol. Water Supply 2012, 12, 658-665. [CrossRef]

34. Hasan, M.M.; Shafiquzzaman, M.; Nakajima, J.; Ahmed, A.T.K.; Azam, M.S. Application of low-cost ceramic filter to Membrane Bioreactor for grey water Treatment. Water Environ. Res. 2015, 87, 233-241. [PubMed]

35. Shafiquzzaman, M.; Al- Mahmoud, A.; Al Saleem, S.S.; Haider, H. Application of a Low-Cost Ceramic Filter for Recycling Sand Filter Backwash Water. Water 2018, 10, 150. [CrossRef]

36. Sakson, G.; Brzezinska, A.; Zawilski, M. Emission of heavy metals from an urban catchment into receiving water and possibility of its limitation on the example of Lodz city. Environ. Monit. Assess. 2018, 190, 281. [CrossRef] [PubMed]

37. APHA. Standard Methods for the Examination of Water and Wastewater, 21st ed.; American Public Health Association: Washington, DC, USA, 2005.

38. U.S. EPA. Method 200.7: Determination of Metals and Trace Elements in Water and Wastes by Inductively Coupled Plasma-Atomic Emission Spectrometry; Revision 4.4; United States Environmental Protection Agency: Cincinnati, OH, USA, 1994.

39. Shafiquzzaman, M.; Hasan, M.M.; Nakajima, J.; Mishima, I. Development of a simple and effective arsenic removal filter based on ceramic filtration. J. Water Environ. Technol. 2011, 9, 333-347. [CrossRef]

40. Zheng, W.Y.; Nigel, G.; Hui-juan, L.; Jiu-hui, Q. Comparison of FeCl3 and alum pre-treatment on UF membrane fouling. Chem. Eng. J. 2013, 234, 158-165.

41. MWE. Technical Guidelines for the Use of Treated Sanitary Wastewater in Irrigation for Landscaping and Agricultural Irrigation; Ministry of Water and Electricity: Riyadh, Saudi Arabia, 2006.

42. World Health Organization (WHO). Guidelines for the Safe Use of Wastewater, Excreta and Greywater, Volume 4: Excreta and Greywater Use in Agriculture; WHO: Geneva, Switzerland, 2006.

43. World Health Organization (WHO). Guidelines for Drinking Water Quality, 2nd ed.; World Health Organization: Geneva, Switzerland, 2004.

44. Saudi Arabian Standards Organization (SASO). Un-Bottled Drinking Water. SASO 701 and mkg 149 (in Arabic); Saudi Arabian Standards Organization (SASO): Riyadh, Saudi Arabia, 2000.

45. Hobbiea, S.E.; Finlaya, J.C.; Jankea, B.D.; Nidzgorskia, D.A.; Milletb, D.B.; Bakerc, L.A. Contrasting nitrogen and phosphorus budgets in urban watersheds and implications for managing urban water pollution. Proc. Natl. Acad. Sci. USA 2017, 114, 4177-4182. [CrossRef]

46. Sandoval, A.D.O.; Brião, V.B.; Fernandes, V.M.C.; Hemkemeier, A.; Friedrich, M.T. Stormwater management by microfiltration and ultrafiltration treatment. J. Water Process Eng. 2019, 30, 100453. [CrossRef]

47. Muschack, W. Pollution of street run-off by traffic and local conditions. Sci. Total Environ. 1990, 93, 419-431. [CrossRef]

48. Pitt, R.; Clark, S.; Field, R. Groundwater contamination potential from stormwater infiltration practices. Urban Water 1999, 1, 217-236. [CrossRef]

49. Duncan, H. Urban Stormwater Quality: A Statistical Overview; Cooperative Research Centre for Catchment Hydrology: Melbourne, Australia, 1999.

50. Ramon, G.; Green, M.; Semiat, R.; Dosoretz, C. Low strength graywater characterization and treatment by direct membrane filtration. Desalination 2004, 170, 241-250. [CrossRef]

51. Kim, J.; Song, I.; Oh, H.; Jong, J.; Park, J.; Choung, Y. A laboratory-scale Graywater treatment system based on a filtration and oxidation Process-Characteristics of graywater from a residential complex. Desalination 2009, 238, 347-357. [CrossRef]

52. Ogunmodede, O.T.; Adebayo, O.L.; Ojo, A.A. Enhancing adsorption capacity of clay and application in dye removal from wastewater. Int. Lett. Chem. Physi. Astron. 2014, 39, 35-51. [CrossRef]

53. Ahiablame, L.M.; Engel, B.A.; Chaubey, I. Effectiveness of low impact development practices: Literature review and suggestions for future research. Water Air Soil Pollut. 2012, 223, 4253-4273. [CrossRef]

54. Zarezadeh, V.; Lung, T.; Dorman, T.; Shipley, H.T.; Giacomoni, M. Assessing the performance of sand filter basins in treating urban stormwater runoff. Environ. Monit. Assess. 2018, 190, 697. [CrossRef]

55. Ferree, M.A.; Shannon, R.D. Evaluation of a second derivative UV/visible spectroscopy technique for nitrate and total nitrogen analysis of wastewater samples. Water Res. 2001, 35, 327-332. [CrossRef] 
56. Uddin, M.K. A review on the adsorption of heavy metals by clay minerals, with special focus on the past decade. Chem. Eng. J. 2017, 308, 438-462. [CrossRef]

57. Veli, S.; Alyüz, B. Adsorption of copper and zinc from aqueous solutions by using natural clay. J. Hazard. Mater. 2007, 149, 226-233. [CrossRef]

58. El Samrani, A.G.; Lartiges, B.S.; Villie'ras, F. Chemical coagulation of combined sewer overflow: Heavy metal removal and treatment optimization. Water Res. 2008, 42, 951-960. [CrossRef]

59. Ghorpade, A.M.; Ahammed, A.A. Water treatment sludge for removal of heavy metals from electroplating wastewater. Environ. Eng. Res. 2018, 23, 92-98. [CrossRef]

60. Crittenden, J.C.; Trussell, R.R.; Hand, D.W.; Howe, K.J.; Tchobanoglous, G. MWH's Water Treatment: Principles and Design; Wiley: Hoboken, NJ, USA, 2012.

61. Sarparastzadeh, H.; Saeedi, M.; Naeimpoor, F.; Aminzadeh, B. Pretreatment of Municipal Wastewater by Enhanced Chemical Coagulation. Int. J. Environ. Res. 2007, 1, 104-113.

62. Zhou, Y.F.; Haynes, R.J. Removal of $\mathrm{Pb}(\mathrm{II}), \mathrm{Cr}(\mathrm{III})$ and $\mathrm{Cr}(\mathrm{VI})$ from aqueous solutions using alum-derived water treatment sludge. Water Air Soil Pollut. 2011, 215, 631-643. [CrossRef]

63. Shafiquzzaman, M.; Alharbi, S.K.; Haider, H.; AlSaleem, S.S.; Ghumman, A.R. Development and Evaluation of Treatment Options for Recycling Ablution Greywater. Int. J. Environ. Sci. Technol. 2019. [CrossRef]

(C) 2020 by the authors. Licensee MDPI, Basel, Switzerland. This article is an open access article distributed under the terms and conditions of the Creative Commons Attribution (CC BY) license (http://creativecommons.org/licenses/by/4.0/). 